\title{
IDENTIFICATION AND QUANTITATIVE DETERMINATION OF FLAVONOID IN AGRIMONIA EUPATORIA
}

\author{
(c) I. V. Kozak, L. V. Vronska, A. E. Demyd, T. A. Hroshovyy \\ I. Horbachevsky Ternopil State Medical University \\ innakozak0@gmail.com
}

\begin{abstract}
The aim of the work. Determination of the qualitative composition of flavonoids in local samples of Agrimony herb according to the requirements of the State Pharmacopoeia of Ukraine (SPU) for flowering tops of Agrimony and development of the methods of quantitative determination of flavonoid content in it is the urgent matter.

Materials and Methods. To study the qualitative composition of flavonoids, four local samples of Agrimony were used; the evaluation of quantitative content of flavonoids was carried out for five samples. A thin-layer chromatography was used to study the qualitative composition and spectrophotometry - to determine the quantitative content of flavonoids. Results and Discussion. The research proved that qualitative composition of flavonoids in Agrimony complied with the requirements of the State Pharmacopoeia of Ukraine for Agrimony flowering tops. To identify the Agrimony, it was suggested to detect flavonoids by thin-layer chromatography, changing the sample preparation of raw materials. Into the reference solution, hyperoside should be added to identify it completely at the chromatogram of the test solution. In electronic absorption spectra of alcohol extracts ( $70 \% \mathrm{~V} / \mathrm{V})$ of Agrimony in conditions of complex formation together with aluminum chloride, the absorption maximum was observed ranging 400-403 nm. Since, the method of quantitative determination of flavonoids was suggested, equivalent to luteolin or luteolin-7-O-glucoside using the value of specific absorption rate of complex flavonoids compounds with aluminum chloride.

Conclusions. Rutin, hyperoside, isoquercitrin were chosen to be identification markers of Agrimony; quercitrin and other flavonoids with nonquercetin aglycones and phenolcarboxylic acids may be evidenced as zones of orange, green and blue fluorescence at the chromatogram of the test solution. The content of flavonoids in five samples was determined within 0.90-1.46 \% equivalent to luteolin or 1.47-2.39\% as luteolin-7-O-glucoside. The difference between the values of content for different samples is associated with various conditions of raw materials growth as well as with the ambiguousness of the notion "herb". Therefore, there is a need for implementation of the national part into the monograph of SPU on Agrimony; the use of Agrimony should be provided and the concept "related substance" with criteria of largest possible quantity of gross stems should be introduced. Taking into account the high content and biological activity of flavonoids, the definition for "flavonoids content" should be adopted in the monograph on Agrimony.
\end{abstract}

Key words: Agrimonia eupatoria; herb; flavonoids; identification; quantitative determination; thin-layer chromatography; spectrophotometry.

Introduction. Hepatobiliary disorders are common pathology. Liver is involved into many processes of the human body and hepatic injury causes serious disorders in metabolism, detoxification, antimicrobial and immune defence. Therefore, effective prevention and treatment of hepatic diseases are the urgent matters of contemporary medicine. About $80 \%$ of hepatoprotectors that are used in clinical practice are of vegetable origin. Agrimony is one of the unique herbs that can be used to treat Hepatobiliary diseases; it possesses antioxidant, anti-inflammatory and choleretic properties [1-4].

Flavan-3-ols (catechin and procyanidins B1, B2, B3, B6, B7, C1, C2 and epicatechin-epicatechin-catechin), quercetin 3-O-glucoside, quercetin 3-O-galactoside, kaempferol 3-O-glucoside, kaempferol 3-O-(6"-O-pcoumaroyl)-glucoside and quercetin glucosides as well as various phenolic acids are identified in Agrimony $[5,6]$.
SPU contains a monograph "Agrimony", which fully conforms to European Pharmacopoeia. In the monograph it is stated that flowering tops are the raw material of Agrimony. The monograph contains macroand microscopic description of the raw materials, methods of identification of flavonoids by thin-layer chromatography (TLC) using rutine and isoquercitroside (isoquercitrin) as standard samples, test "loss on drying" and "total ash", technique of tannins content evaluation [7]. There are no national additaments to this monograph. Agrimony is used in complementary medicine and formal drugs production (Prostalad tincture, manufacturer Biolik JSC, Ukraine); the characteristic feature of this medicinal herb raw material is that the herb, which is an aboveground part of the plant, is the local raw material; that is why its quality indices may vary from those for flowering tops listed in the monograph.

ISSN 2312-0967. Фармацевтичний часопис. 2017. № 2 
The analysis of the literature and the SPU requirements regarding the identification of flavonoids demonstrate the urgent issue of further research and determination of flavonoids in Agrimony. Due to the unlimited opportunities for drugs production using this herb raw material, it was decided to examine more profoundly the flavonoid composition and content in local Agrimony samples and offer the methods of their quantitative determination for quality control of raw materials and drugs made of it.

The objective of our study is the qualitative determination of flavonoids in local samples of common Agrimony due to the SPU requirements for Agrimony flowering tops and development of methods of flavonoids evaluation in it.

Materials and Methods. Agrimony samples collected in Ternopil, Ivano-Frankivsk and Chernivtsi regions were used in the research.

Research on the qualitative content of flavonoids was performed by the method of thin-layer chromatography (TLC); the quantitative determination was performed by the method of spectrophotometry.

To determine the flavonoids composition in local Agrimony samples the conventional solvent system was used according to the SPU monograph on Agrimony: formic acid - water - ethyl acetate (10:10:80). Methanol extraction of flavonoids was performed by boiling in water bath and reflux condenser of $1.0 \mathrm{~g}$ of powdered raw material and $25.0 \mathrm{ml}$ of methanol for 1 hour. To determine the flavonoids composition $20 \mu \mathrm{l}$ of the extracted methanol was placed on a chromatographic plate. The chromatograms study was performed at ultraviolet light, wavelength $365 \mathrm{~nm}$, after their treating with methanol solutions of $10 \mathrm{~g} / \mathrm{l}$ diphenylboric acid aminoethyl ester and $50 \mathrm{~g} / \mathrm{l}$ macrogol 400 solution.

Standard samples of rutin, hyperoside, apigenin-7glucoside, luteolin-7-glucoside, isoquercitrin, quercitrin, luteolin, quercetin, apigenin, chlorogenic and caffeic acids (Sigma-Aldrich, Fluka) were used for identification of flavonoids. Chromatographic plates Silica gel $60 \mathrm{~F}_{254}$ (Merck, Germany), chromatographic chambers, a spotting device Linomat 5 and a lamp for chromatograms studying at ultraviolet light (CAMAG, Switzerland) were used in the TLC method.

The values for methanol, ethanol, ethyl acetate, glacial acetic acid, formic acid anhydrous, aminoethyl ester, diphenylboric acid and macrogol 400, aluminum chloride were used according to the SPU requirements; they were used for further mixing of solutions or mobile phases [7].

Results and Discussion. The results of Agrimony samples study by TLC are presented in Fig. 1.

The results of TLC study lead to the conclusions that the identification markers for flowering tops of Agrimony declared in the Pharmacopoeia monograph: rutin, hyperoside and isoquercitrin are present in all Agrimony samples. In the pharmacopeia report it is also stated that at the chromatogram there was a zone that conforms to quercitrin. Only one sample (the third one) was identified as quercitrin at the chromatograms of the studied samples.

However, it should be noted that some additional flavonoids zones at the tracks of all samples were

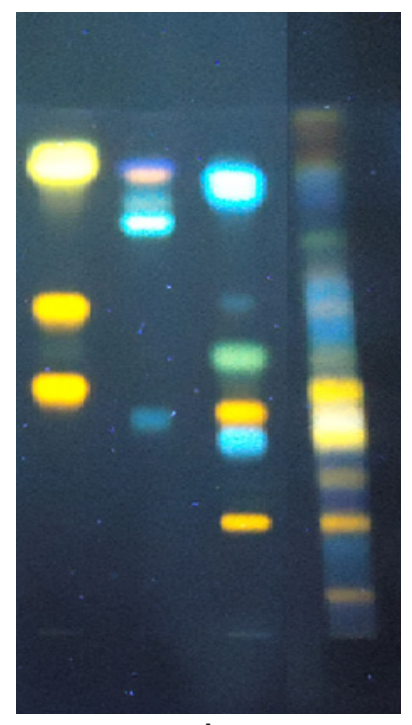

A

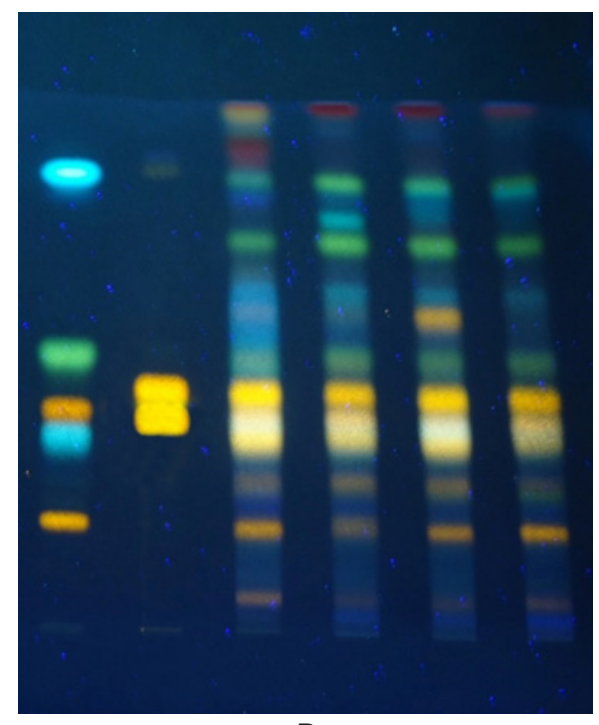

B

Fig. 1. The chromatograms that were obtained during identification of flavonoids in Agrimony. The chromatogram A: track 1 - reference solution (isoquercitrin, quercitrin, luteolin, apigenin, quercetin); track 2 - reference solution (chicoric acid, myricetin, ferulic acid); track 3 - reference solution (rutin, chlorogenic acid, hyperoside, apigenin-7-O-glucoside, rosmarinic and caffeic acids); track 4 - methanol extraction of the sample 1 out of Agrimony. The chromatogram B: track

1 - reference solution (rutin, chlorogenic acid, hyperoside, apigenin-7-O-glucoside, caffeic acid); track 2 - reference solution (luteolin-7-O-glucoside and isoquercitrin); tracks 3-6 - methanol extraction of the samples 1-4 out of Agrimony.

Zone arrangement of the standard samples should be studied from top to bottom in order they were considered.

ISSN 2312-0967. Pharmaceutical review. 2017. № 2 
observed: two slight ones - below and above the rutine zone; a very intense zone at the chlorogenic acid zone; between the chlorogenic acid zone and hyperoside zone there was a very intense zone of slightly yellow fluorescence, which may belong to flavonoid with nonquercetin aglycone (due to fluorescence colouring); an intense zone of apigenin-7-O-glucoside in samples 2-4 and a weak one in the first sample; at the track of each sample two zones with intense green fluorescence was observed: the first one - below the chicoric acid zone and the second - at the apigenin zone.

It should be noted that herb phenol carboxylic acids are in Agrimony, particularly in case of methanol extract of the first sample on the chromatogram two very intense zones of blue fluorescence above and below the quercitrin zone are observed; in methanol extracts of three other samples these zones are of significantly lower fluorescence. Contrary to other, the second Agrimony sample also contains chicoric acid, which at the chromatogram of the reference sample is observed as an intense zone of blue fluorescence at chicoric acid zone; the samples 3 and 4 contain caffeic acid that somewhat merges with the apigenin zone at the top of the chromatogram.

Thus, the results of chromatographic study of four Agrimony samples prove their compliance with the SPU requirements for identification of Agrimony flowering tops flavonoids.

The data obtained point out the different composition of flavonoids, which is not limited to four compounds, as listed in the SPU requirements. By means of high performance liquid chromatography using different detectors [5], in water-alcohol and ethyl acetate fractions of Agrimonia eupatoria such flavonoids were found out: quercetin 3-O-glucoside, quercetin 3-O-galactoside, kaempferol 3-O-glucoside, kaempferol 3-O-(6"-O-pcoumaroyl)-glucoside, apigenin 6-C-glucoside, and various phenolic acids; whereas the authors [4] for this type of raw material by HPLC/DAD in methanol extracts established hyperoside, isoquercitrin, rutin, apigenin-Oglucoside, apigenin-6-C-glucoside (isovitexin) and two compounds, which had not been identified before. The authors [8] by TLC in the aqueous extract identified myricetin, azoleantin, vitexin and isoorientin, and the methanol extract contained kaempferol, quercetin, isorhamnetin and myricetin. In the research [9], the results of isolation and identification of ten flavonoids were described: kaempferol 3-O- $\beta-D-(2 "-O-a c e t y l)$ glucopyranoside, tiliroside, astragalin, apigenin 7-O- $\beta$ D-glucuronide, rutin, isoquercitrin, quercitrin, luteolin 7-O- $\beta$-D-glucuronide and luteolin 7-O- $\beta$-D-glucopyranoside and for the first time kaempferol 3-O- $\beta-D-(2 "-$ O-acetyl-6"'-(E)-p-coumaroyl)-glucopyranoside (2"-acetyl-tiliroside) was identified. Data on the presence of hyperoside, rutin, isoquercitrin, quercitrin, isovitexin; apigenin, its 7-O-glucoside, 7-O- $\beta$-D-glucuronide; kaempferol, its 3-glucoside, 3-rhamnoside, 3-rutinoside,
7-O- $\beta$-D-glucuronide, malonyl hexoside, hexoside, 4'-methyl ether (kaempferide), kaempferide 3-rhamnoside; luteolin, its glucuronide isomer, 7-O-glucoside, 7-O-glucuronide; quercetin, its 3-O-rhamnoside, rhamnoglucoside isomer, malonyl hexoside isomers were presented by the authors [10].

Thus, comparing the obtained data with the literature and the SPU requirements on raw material of Agrimony flowering tops, to identify Agrimony the chromatographic detection of flavonoids should be performed. The presence of three zones of flavonoids at chromatograms of the test solution: rutin, hyperoside and isoquercitrin, and the possible additional quercitrin zone should be a quality criterion. The chromatogram example of the test solution presented in SPU describes requirements ambiguously: without knowing the exact position of hyperoside zone it is difficult to determine the hyperoside zone on the test solution chromatogram. Since, due to the analysis of the literature and research results, several additional zones of flavonoids are observed and should be evidenced. In this regard, hyperoside should be added into the comparison solution together with routine and isoquercitrin to identify Agrimony that is the available standard. It is important to point out that at the chromatogram of the test solution above the isoquercitrin zone there are three zones of bright green fluorescence, which may include apigenin glycosides and kaempferol, and the emergence of zones with blue fluorescence (phenol carboxylic acid) is presumable.

Due to the above issues, to identify common Agrimony the method of flavonoids detection by TLC is suggested, by changing in Pharmacopoeial method the sample preparation of raw material: improving the composition of the reference solution and quality criteria.

Method of Agrimony flavonoids identification

Test solution. $1.0 \mathrm{~g}$ of the powdered raw material is placed into a $50 \mathrm{ml}$ conical flask and $25 \mathrm{ml}$ of methanol is added and boiled under a reflux condenser in a water bath for 1 hour. Allow the flask with the solution to cool and the extract is filtered by a paper filter into a $25 \mathrm{ml}$ measuring flask decanting the liquid. The flask with the raw material and the filter are rinsed with methanol $R$ diluting the volume of the filtrate up to the mark, and mixed.

Reference solution. $5.0 \mathrm{mg}$ of rutin CRS (Fluka), $5.0 \mathrm{mg}$ of hyperoside CRS (SPU), $5.0 \mathrm{mg}$ of isoquercitroside (isoquercitrin) CRS (Fluka) are dissolved in $10.0 \mathrm{ml}$ of methanol $R$.

Plate: TLC silica gel R plate.

Mobile phase: anhydrous formic acid $R$ - water $R$ ethyl acetate (10:10:80) (VN/V).

Sample volume applied: $20.0 \mu \mathrm{l}$ of the test solution and $10.0 \mu \mathrm{l}$ of the reference solution in $1 \mathrm{~cm}$ bands.

Development: $12 \mathrm{~cm}$ from the spotting line.

Drying after the chromatography: in air.

Drying before development: in the drying cabinet at $100-105^{\circ} \mathrm{C}$ for $10 \mathrm{~min}$.

ISSN 2312-0967. Фармацевтичний часопис. 2017. № 2 
Detection: a still-warm plate is sprayed with $10 \mathrm{~g} / \mathrm{l}$ of diphenylboric acid aminoethyl ester $R$ in methanol $R$, dried in air; then the plate is sprayed with $50 \mathrm{~g} / \mathrm{l}$ of macrogol $400 R$ in methanol $R$, dried in air for 30 min and studied at ultraviolet light, wavelength $365 \mathrm{~nm}$.

Results: at the reference solution chromatogram three yellow-orange fluorescent zones of rutin, hyperoside and isoquercitroside (isoquercitrin) should be identified (in order of $\mathrm{R}_{\mathrm{f}}$ (retardation factor) increase).

At the test solution chromatogram three orange fluorescent zones should be detected at rutin, hyperoside and isoquercitroside (isoquercitrin) levels of the reference solution chromatogram. Other zones of yellow-orange fluorescence between the rutin and hyperoside zones, an orange fluorescent zone over the isoquercitroside zone - quercitroside (quercitrin) zone, bright green and blue fluorescent zones over the isoquercitroside zone (other flavonoids and phenolcarboxylic acids) may be evidenced.

The sequence of the zones at the chromatograms of the reference and test solutions is presented in Fig. 2 .

To determine the quantitative content of flavonoids a spectrophotometric method was suggested that allows determining the total content. During the study of the spectra of alcohol (70\% (V/V) extracts absorption of Agrimony medicinal herb raw material (samples 1-4) (Fig. 3) by complexation with aluminum chloride it was found out that the maximum absorbance was at a wavelength $(400 \pm 3) \mathrm{nm}$ as well as the maximum absorbance of the complex of luteolin with aluminum chloride under similar conditions [11]. Position of the maximum absorbance at $400 \mathrm{~nm}$ is caused by the cumulative impact of absorption of various aglycones complex compounds (quercetin, kaempferol, apigenin, luteolin) $[4,5,8-10]$ and their glycosides with aluminum chloride, which are formed in a $70 \%$ ethanol medium. Therefore, for standardization of absorption evaluation conditions, it was decided to carry out the recalculation of the amount of flavonoids by luteolin using specific absorbance value of luteolin with aluminum chloride complex at a wavelength of $400 \mathrm{~nm}$ [12]. It is noteworthy that for the quantitative determination of flavonoids in different kinds of Agrimony flowering tops [4] recalculation by quercetin was applied, so the complex of flavonoids with aluminum chloride in the methanol medium was obtained and the absorption at a wavelength of $425 \mathrm{~nm}$ was evaluated. The authors [13] suggested performing recalculation of flavonoid content in Agrimony raw material by rutin using $50 \%$ ethanol to extract flavonoids out of the raw material; to receive the photometric compound using $95 \%$ ethanol medium and evaluating of absorbance at a wavelength of $405 \mathrm{~nm}$.

During the development of the methods of quantitative determination of flavonoids, the influence of the ethanol concentration and sample preparation time on the degree of flavonoids extraction was studied. It was proved that an exhaustive extraction of flavonoids out of raw material $70 \%$ ethanol should be used. The tests on the influence of time of raw material boiling with extractant on flavonoids separation revealed that a threefold extraction during 30, 15 and 15 minutes consecutively is optimal.

Method of quantitative determination of flavonoids

Stock solution. $0.5 \mathrm{~g}$ (exact weight) of the powdered raw material is placed into a $100 \mathrm{ml}$ flat-bottom flask and $50.0 \mathrm{ml}$ of ethanol (70\% (V/V) is added and boiled under a reflux condenser in a water bath for 30 minutes. The

\begin{tabular}{|c|c|}
\hline \multicolumn{2}{|c|}{ Top of the plate } \\
\hline & $\begin{array}{l}\text { an orange fluorescent zone } \\
\text { mav be present (quercitroside) }\end{array}$ \\
\hline $\begin{array}{l}\text { Isoquercitroside: an orange } \\
\text { fluorescent zone } \\
\text { Hyperoside: an orange } \\
\text { fluorescent zone }\end{array}$ & $\begin{array}{l}\text { an orange fluorescent zone } \\
\text { (isoquercitroside) } \\
\text { an orange fluorescent zone } \\
\text { (hyperoside) }\end{array}$ \\
\hline $\begin{array}{l}\text { Rutin: an orange fluorescent } \\
\text { zone }\end{array}$ & $\begin{array}{l}\text { an orange fluorescent zone } \\
\text { (rutin) }\end{array}$ \\
\hline Reference solution & T est solution \\
\hline
\end{tabular}

Fig. 2. TLC chromatogram scheme of Agrimony flavonoids identification after its treating with solutions of aminoethyl ester diphenylboric acid and macrogol 400 and studying at ultraviolet light, wavelength $365 \mathrm{~nm}$.

ISSN 2312-0967. Pharmaceutical review. 2017. № 2 
Фітохімічні дослідження Phytochemical researches

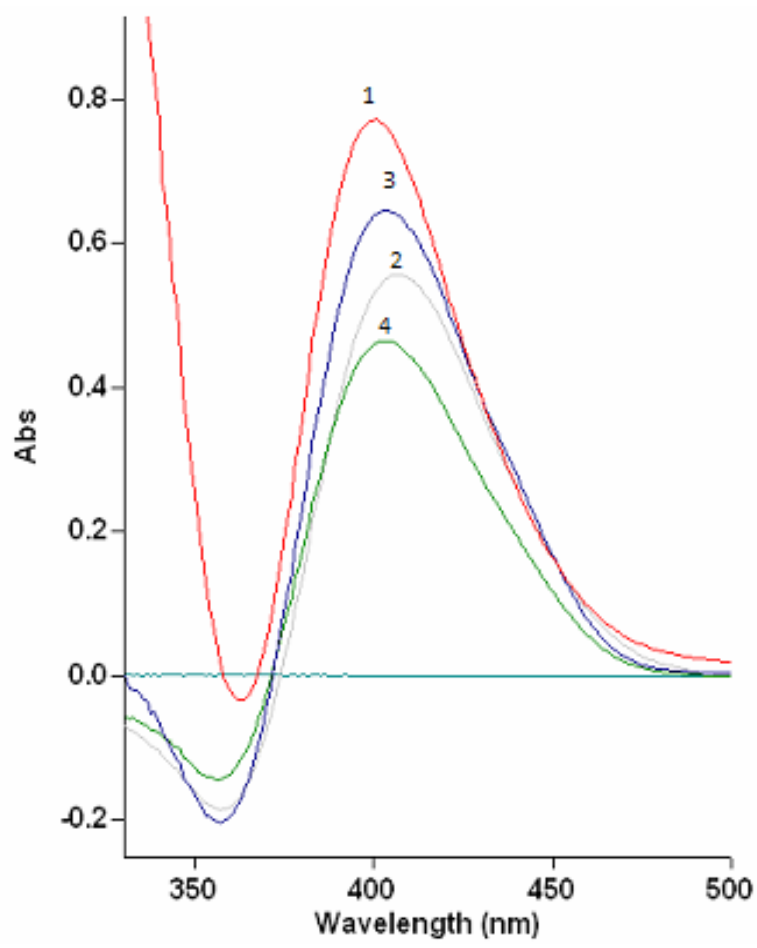

Fig. 3. The differential electronic absorption spectra of the test solutions in terms of quantification of flavonoids in common Agrimony raw material (the samples 1-4 of raw materials).

flask with the solution is cooled and the extract is filtered by a paper filter into a $100 \mathrm{ml}$ measuring flask decanting the liquid. $30.0 \mathrm{ml}$ of ethanol (70\% (V/V) is added into the meal in the flask and boiled in a water bath under $a$ reflux condenser for 15 minutes. The flask with the solution is cooled and the extract is filtered into the same measuring flask, combining the filtrates. To the meal in the flask $15.0 \mathrm{ml}$ of ethanol $(70 \%(\mathrm{~V} / \mathrm{V})$ is added and boiled in a water bath under a reflux condenser for 15 minutes. The flask with the solution is cooled and the extract is filtered into the same measuring flask, combining the filtrates. The meal in the flask and the filter are rinsed with ethanol (70 \% (V/V) diluting the volume of the filtrate up to the mark, and mixed.

Test solution. $5.0 \mathrm{ml}$ of the stock solution is placed into a $25 \mathrm{ml}$ measuring flask, 3,0 $\mathrm{ml}$ of $3 \%$ alcohol (70\% $(\mathrm{V} / \mathrm{V})$ ) solution of aluminum chloride is added and the volume of the solution is diluted up to the mark with ethanol $(70 \%(\mathrm{~V} / \mathrm{V}))$ and mixed.

Compensation solution. $5.0 \mathrm{ml}$ of the stock solution is placed into a $25 \mathrm{ml}$ measuring flask and the volume of the solution is diluted up to the mark with ethanol (70\% (V/V), and mixed.

The absorption of the test solution is evaluated in 45 minutes after mixing at wavelength $400 \pm 2 \mathrm{~nm}$ relatively to the compensation solution.

The flavonoids amount in raw material $(X)$, in per cents, equivalent to a luteolin (or luteolin-7-O-glucoside) and dry raw material is calculated from the formula:

$$
X=\frac{A \times 5 \times 100 \times 100}{E \times m \times(100-W)},
$$

A - absorbance of the test solution;

$\mathrm{m}$ - mass of sample raw material, $\mathrm{g}$;

E - specific absorbance of luteolin (549) or luteolin-7O-glucoside (335) complex with aluminum chloride in conditions of quantitative determination, wavelength $400 \mathrm{~nm}[12,10]$;

W - loss on drying, \%.

Due to the suggested method, the quantitative content of flavonoids in five local samples of common Agrimony was defined; the results are presented in the Table 1.

The obtained values of flavonoids content differ in various samples of raw materials due to the conditions of their growth, harvesting and relativeness of the term «herb» as raw material. It was proved that after powdering the raw material, the content of «small»fraction significantly varied in different samples: from $64 \%$ to $76 \%$ that certainly influenced the total flavonoid content in the samples because the average raw material sample, including «fine» and «coarse» fractions, was used for determination. Evidently, there is a need for the introduction of a national part into SPU that would explain the «coarse» fraction content, which consists of hard grinding parts of stems.

In the literature on the results of quantitative determination of flavonoids content in Agrimony raw materials, the data vary depending of the type of material (top, herb), its origin, identification method and standards for content determination. Thus, by spectrophotometric determination: in local Agrimony samples 0.90-1.46\% of flavonoids was obtained equivalent to luteolin or 1.47-2.39 \% - equivalent to luteolin-7-O-glucoside; in

Table 1. The results of quantitative determination of flavonoids in common Agrimony

\begin{tabular}{|c|c|c|}
\hline Sample, origin & $\begin{array}{c}\text { Flavonoids content, equivalent to } \\
\text { luteolin, \% }\end{array}$ & $\begin{array}{c}\text { Flavonoids content, equivalent to } \\
\text { luteolin-7-O-glucoside, \% }\end{array}$ \\
\hline Sample 1, Ternopil region & $1.46 \pm 0.01$ & $2.39 \pm 0.01$ \\
\hline Sample 2, Ivano-Frankivsk region & $1.05 \pm 0.02$ & $1.72 \pm 0.02$ \\
\hline Sample 3, Ternopil region & $1.25 \pm 0.02$ & $2.05 \pm 0.02$ \\
\hline Sample 4, Chernivtsi region & $0.90 \pm 0.02$ & $1.47 \pm 0.02$ \\
\hline Sample 5, Ternopil region & $0.94 \pm 0.01$ & $1.54 \pm 0.01$ \\
\hline
\end{tabular}

ISSN 2312-0967. Фармацевтичний часопис. 2017. № 2 
the research [4] for flowering aerial parts of Czech samples of Agrimony $3.5 \%$ of flavonoids was obtained equivalent to quercetin; for local samples of Agrimony 1.39-1.62 \% of flavonoids was detected equivalent to rutin [13]; by chromatographic determination (HPLC/ DAD) of Polish samples of Agrimony $8.2-10.9 \mathrm{mg} / \mathrm{g}$ (0.82-1.09\%) of flavonoids were obtained [14]. As the authors [14] note, flavonoids are the second main group of biologically active substances in different species of Agrimony. By determining the total flavonoids of Agrimony, the authors [15] obtained the content within 1.22-1.40\% equivalent to cynaroside (luteolin-7-Oglucoside) and specified that the procurement of raw materials was carried out by cutting off the aerial parts of the plants at a height 8-10 cm below the soil. Also in the viewing message the content $1.9 \%$ of flavonoids (mainly hyperoside $(0.37 \%)$ together with rutin, isoquercitrin, quercitrin, isovitexin (apigenin-6-C-glucoside) [10] is mentioned.

The infusion of Agrimony actively absorbs radicals 2.2-diphenyl-1-picrylhydrazyl (DPPH) [16]. It was proved that flavonoids of Agrimony herb exhibit antioxidant activity and could be used to treat inflammation, cancer, diabetes, possessed a neuroprotective effect on glutamate-induced toxity in HT22 cells, hepatoprotective effect on chronic ethanol-induced liver injury in rats, prevented hepatitis B virus [8, 9, 17-20]. According to the results of the research and the literature data on biological activity of Agrimony flavonoids in the national part of the monograph on Agrimony, the determination of this biologically active substances content should be introduced.
Conclusions. 1. The research has proved that qualitative composition of flavonoids in common Agrimony complies with the requirements of the State Pharmacopoeia of Ukraine for Agrimony flowering tops. To identify the Agrimony it was suggested to detect flavonoids by thin-layer chromatography, changing the sample preparation of raw materials. Into the reference solution, hyperoside should be added to identify it completely at the chromatogram of the test solution. Rutin, hyperoside, isoquercitrin were suggested to be identification markers of Agrimony; quercitrin and other flavonoids with nonquercetin aglycones and phenolcarboxylic acids may be evidenced as zones of orange, green and blue fluorescence at the chromatogram of the test solution.

2. The method of quantitative determination of flavonoids, equivalent to luteolin or luteolin-7-O-glucoside, was suggested. The content of flavonoids in five samples was determined within $0.90-1.46 \%$ equivalent to luteolin or $1.47-2.39 \%$ as luteolin-7-O-glucoside. The difference between the values of content for different samples is associated with various conditions of raw materials growth as well as with the ambiguousness of the notion "herb" as a raw material.

3. There is a need for implementation of the national part into the monograph of SPU on Agrimony; the use of Agrimony should be provided and the concept "related substance" with criteria of largest possible quantity of gross stems should be introduced. Taking into account the high content and biological activity of flavonoids, the definition for "flavonoids content" should be adopted in the monograph on Agrimony.

\title{
ІДЕНТИФІКАЦІЯ І КІЛЬКІСНЕ ВИЗНАЧЕННЯ ВМІСТУ ФЛАВОНОӤДІВ У ТРАВІ ПАРИЛА ЗВИЧАЙНОГО
}

\author{
І. В. Козак, Л. В. Вронська, А. Є. Демид, Т. А. Грошовий \\ ДВНЗ «Тернопільський державний медичний університет імені І. Я. Горбачевського моз України» \\ innakozak0@gmail.com
}

Мета роботи. Встановлення відповідності якісного складу фрлавоноїдів вітчизняних зразків трави парила звичайного вимогам, наведеним у ДФУ для квітучих верхівок парила та розробка методики кількісного визначення суми фрлавоноїдів у ній.

Матеріали і методи. Для дослідження якісного складу фрлавоноїдів використано чотири вітчизняні зразки трави парила звичайного, в п'яти зразках проводили оцінку кількісного вмісту фрлавоноїдів. У роботі використано тонкошарову хроматографрію при вивченні якісного складу і спектрофотометрію при визначенні кількісного вмісту фрлавоноїдів.

Результати й обговорення. Проведені дослідження вказали на відповідність якісного складу фрлавоноїдів трави парила звичайного вимогам ДФУ для парила квітучих верхівок. Для встановлення тотожності трави парила звичайного запропоновано ідентифрікувати фрлавоноїди методом тонкошарової хроматограсрії, змінивши пробопідготовку сировини. У розчин порівняння додатково слід вносити гіперозид, щоб однозначно ідентисрікувати його на хроматограмі випробовуваного розчину. В електронних спектрах поглинання, отриманих для спиртових витягів (70 \%, об/об) з трави парила звичайного в умовах комплексоутворення 3 алюміній хлоридом, максимум поглинання спостерігається в діапазоні 400-403 нм. Зважаючи на це, запропоновано методику кількісного визначення суми фрлавоноїдів у перерахунку на лютеолін або лютеолін-7-О-глюкозид, використовуючи значення питомих коефріцієнтів поглинання комплексних сполук вказаних фрлавоноїдів з алюміній хлоридом.

ISSN 2312-0967. Pharmaceutical review. 2017. № 2 
Фітохімічні дослідження

Phytochemical researches

Висновки. Ідентифікаційними маркерами трави парила обрано рутин, гіперозид, ізокверцитрин; передбачено можливість присутності кверцитрину та інших фрлавоноїдів з некверцетиновими агліконами і френолкарбонових кислот у вигляді зон оранжевої, зеленої і блакитної фрлуоресценції на хроматограмі випробовуваного розчину. Вміст фрлавоноїдів у досліджуваних п'яти зразках знаходився у межах 0,90-1,46 \% у перерахунку на лютеолін або 1,47-2,39 \% у перерахунку на лютеолін-7-О-глюкозид. Відмінність значень вмісту для різних зразків пов'язується як з різними умовами зростання сировини, так і з невизначеністю поняття «трава». Тому є потреба у введенні національної частини в монограсрію ДфУ на парило, в якій передбачити застосування трави парила, а також ввести показник «Сторонні домішки» із критерієм граничного вмісту грубих стебел. Зважаючи на високий вміст і біологічну активність фрлавоноїдів, у монографії для трави парила слід запровадити визначення вмісту фрлавоноїдів.

Ключові слова: парило звичайне; трава; фрлавоноїди; ідентифікація; кількісне визначення; тонкошарова хроматограсрія; спектрофотометрія.

\title{
ИДЕНТИФИКАЦИЯ И КОЛИЧЕСТВЕННОЕ ОПРЕДЕЛЕНИЕ СОДЕРЖАНИЯ ФЛАВОНОИДОВ В TРАВЕ РЕПЕШКА ОБЫКНОВЕННОГО
}

\author{
И. В. Козак, Л. В. Вронска, А. Е. Демид, Т. А. Грошовый \\ ГВУЗ «Тернопольский государственный медицинский университет имени И.Я. Горбачевского Мз \\ Украины» \\ innakozak0@gmail.com
}

Цель работы. Установление соответствия качественного состава фрлавоноидов отечественных образцов травы репешка обыкновенного требованиям, приведенным в ГФУ для цветущих верхушек репешка и разработка методики количественного определения суммы фрлавоноидов в ней.

Материалы и методы. Для исследования качественного состава фрлавоноидов были использованы четыре отечественные образцы травы репешка обыкновенного, в пяти образцах проводили оценку количественного содержания фрлавоноидов. В работе были использованы тонкослойная хроматография при изучении качественного состава и спектрофотометрия при определении количественного содержания фрлавоноидов.

Результаты и обсуждение. Проведенные исследования указали на соответствие качественного состава фрлавоноидов травы репешка обыкновенного требованиям ГФУ для репешка цветущих верхушек. Для установления тождественноститравырепешкаобыкновенногопредложеноидентифицироватьфрлавоноидыметодомтонкослойной хроматографии, изменив пробоподготовку сырья. В раствор сравнения следует дополнительно вносить гиперозид, чтобы однозначно идентифицировать его на хроматограмме испытуемого раствора. В электронных спектрах поглощения, полученных для спиртовых извлечений (70 \%, об/об) травы репешка обыкновенного в условиях комплексообразования с алюминия хлоридом, максимум поглощения наблюдается в диапазоне 400-403 нм. Учитывая это, была предложена методика количественного определения суммы фрлавоноидов в пересчете на лютеолин или лютеолин-7-О-глюкозид, используя значения удельных показателей поглощения комплексных соединений указанных фрлавоноидов с алюминий хлоридом.

Выводы. Идентификационными маркерами травы репешка обыкновенного предложены рутин, гиперозид, изокверцитрин; предусмотрена возможность присутствия кверцитрина и других фрлавоноидов с некверцетиновыми агликонами и фенолкарбоновых кислот в виде зон оранжевой, зеленой и голубой фрлуоресценции на хроматограмме испытуемого раствора. Содержание фрлавоноидов в пяти исследуемых образцах находилось в пределах 0,90$1,46 \%$ в пересчете на лютеолин или 1,47-2,39 \% в пересчете на лютеолин-7-О-глюкозид. Разброс значений для различных образцов связывается как с разными условиями произростания сырья, так и с условностью понятия «трава», как сырье. При отсутствии требований относительно доли грубых стеблей в сырье, содержание биологически активных веществ всегда будет существенно варьировать. Поэтому есть необходимость во введении национальной части в монографию ГФУ на репешок, в которой предусмотреть применение травы репешка, ввести показатель «Посторонние примеси» с критерием предельного содержания грубых стеблей. Учитывая высокое содержание и биологическую активность фрлавоноидов, в статью для травы репешка следует ввести определение содержания фрлавоноидов.

Ключевые слова: репешок обыкновенный; трава; фрлавоноиды; идентификация; количественное определение; тонкослойная хроматография; спектрофротометрия.

ISSN 2312-0967. Фармацевтичний часопис. 2017. № 2 


\section{Список літератури}

1. Al-Snafi A. E. The pharmacological and therapeutic importance of Agrimonia eupatoria - A review // Asian Journal of Pharmaceutical Science and Technology. - 2015. Vol. 5, Iss. 2. - P. 112-117.

2. European Medicines Agency. Committee on Herbal Medicinal Products (HMPC). Assessment report on Agrimonia eupatoria L., herba: 1-20. Available from: http://www. ema.europa.eu/docs/en_GB/document_library/Herbal_HMPC_assessment_report/2015/04/WC500185275.pdf

3. Ghaima K. K. Antibacterial and wound healing activity of some Agrimonia eupatoria extracts / K. K. Ghaima // J. Baghdad for Sci. - 2013. - Vol. 10(1). - P. 152-160. Availlable from: http://www.iasj.net/iasj?func=fulltext\&ald=69402 4. Kubinova R. Antioxidant and a-glucosidase inhibition activities and polyphenol content of five species of Agrimonia genus / R. Kubinova, D. Jankovska, V. Bauerova // Acta Fytotechnica et Zootechnica. - 2012. - Iss. 2. - P. 38-41.

5. Polyphenolic profile characterization of Agrimonia eupatoria $\mathrm{L}$. by HPLC with different detection devices / $\mathrm{H}$. Correia, A. Gonzales-Paramas, M. T. Amaral [at al.] // Biomed. Chromatogr. - 2006. - Vol. 20 (1). - P. 88-94.

6. Agrimony herb health benefit information by Ray Sahelian, M.D. Complementary medicine newsletter. February 4 2015. http://www.raysahelian.com/agrimony.html

7. Державна фрармакопея України: в 3 т. /Державне підприємство «Український науковий фрармакопейний центр якості лікарських засобів». - 2-е вид. - Х. : ДП «Український науковий фрармакопейний центр якості лікарських засобів», 2015.

8. Ali H. Ad'hiah Cytotoxic effects of Agrimonia eupatoria L. against cancer cell lines in vitro / Ali H. Ad'hiah, Orooba N.H. Al-Bederi, Khulood W. Al-Sammarrae // J. of the Association of Arab Universities for Basic and Applied Sciences. - 2013. - Iss. 14. - P. 87-92.

9. Effect of neuroprotective flavonoids of agrimonia eupatoria on glutamate-induced oxidative injury to HT22 hippocampal Cells / Ki Yong Lee, Lim Hwang, Eun Ju Jeong [at al.] // Biosci. Biotechnol. and Biochem. - 2010. - Iss. 74 (8). - P. 1704-1706.

10. AGRIMONIA - AGRIMONY (AGRIMONIAE HERBA). Available from: https://herbalref.com/agrimonia-agrimonyagrimoniae-herba/

11. Спектрофоотометричне визначення орлавоноїдів у плодах моркви дикої / М. Б. Чубка, Л. В. Вронська, С. В. Сур [та ін.] // Медична хімія. - 2011. - Т.13, № 1. - С. 88-94.

12. Евдокимова О. В. Валидация методики количественного определения суммы фрлавоноидов в столбиках с рыльцами кукурузы / О. В. Евдокимова // Фармация. - 2008. - № 7. - С. 14-17.

13. Шумова Г. С. Розробка методики кількісного визначення фрлавоноїдів різних видів лікарської рослинної сировини спектрофотометричним методом та визначення її валідаційних характеристик / Г. С. Шумова, В. А. Георгіянц, О. А. Євтіфєєва // Фітотерапія. Часопис. - 2013. - № 2. - C. 48-52.

14. Development and validation of HPLC-DAD-CADMS3 method for qualitative and quantitative standardization of polyphenols in Agrimoniae eupatoriae herba (Ph. Eur) / S. Granica, K. Krupa, A. Klebowska [at al.] // J. of Pharmaceutical and Biomedical Analysis. - 2013. - Vol. 86, Iss. 12. - P. 112-122.

15. Куркина А. В. Методика количественного определения суммы фрлавоноидов в траве репешка аптечного / А. В. Куркина // Хим.-срарм. журн. - 2011. T. 45, № 1. - C. 31-34.

16. Correia H. S. The activity of an extract and fraction of Agrimonia eupatoria L. against reactive species / H. S. Correia, M. T. Batista, T. C. P. Dinis // Bio Factors. - 2007. Vol. 29, Iss. 2-3. - P. 91-104.

17. Antioxidant, Anti-Inflammatory and Analgesic Activities of Agrimonia eupatoria L. Infusion / T. N. Santos, G. Costa, J. P. Ferreira [at al.] // Evidence-Based Complementary and Alternative Medicine

Volume. - 2017. Published 12 April 2017. Available from: https://doi.org/10.1155/2017/8309894

18. Agrimonia eupatoria protects against chronic ethanolinduced liver injury in rats / Seon-Jin Yoon, Eun-Ji Koh, Chang-Soo Kim [at al.] // Food and Chemical Toxicology. - V. 50, Iss. 7. - P. 2335-2341.

19. Dur Han Kwon. Inhibition of hepatitis B virus by an aqueous extract of Agrimonia eupatoria L. / Dur Han Kwon // Phytotherapy Research. - 2005. - Vol. 19, Iss. 4. P. 355-358.

20. Zhang J. Studies on the lowering blood sugar substances from agrimony / J. Zhang, Y. Chen // Journal of Chinese Medicinal Materials. - 2009. - Vol. 32. - P. 1537-1539.

\section{References}

1. Al-Snafi AE. The pharmacological and therapeutic importance of Agrimonia eupatoria. A review. Asian J Pharm Sci Tech. 2015;5(2): 112-7.

2. European Medicines Agency. Committee on Herbal Medicinal Products (HMPC). Assessment report on Agrimonia eupatoria L., herba: 1-20. Available from: http://www. ema.europa.eu/docs/en_GB/document_library/Herbal_HMPC_assessment_report/2015/04/WC500185275.pdf

3. Ghaima KK. Antibacterial and wound healing activity of some Agrimonia eupatoria extracts. Baghdad Sci J. 2013;10(1): 152-160. Available from: http://www.iasj.net/ iasj?func $=$ fulltext\&ald $=69402$

4. Kubinova R, Jankovska D, Bauerova V. Antioxidant and

$\alpha$-glucosidase inhibition activities and polyphenol content of five species of Agrimonia genus. Acta fytotechnica et zootechnica. 2012;2: 38-41. Available from: http://www.acta. fapz.uniag.sk/journal/index.php/on_line/article/view/25

5. Correia H, Gonzalez-Paramas A, Amaral MT, SantosBuelga C, Batista MT. Polyphenolic profile characterization of Agrimonia eupatoria L. by HPLC with different detection devices. Biomed. Chromatogr. 2006 Jan;20(1): 88-94. Available from: DOI: $10.1002 / \mathrm{bmc} .533$

6. Ray Sahelian MD. Agrimony herb health benefit information by Complementary medicine newsletter. 2016 Feb [cited 2016 Feb 4];102(6):[about 1 p.]. Available from: http:// www.raysahelian.com/agrimony.html

ISSN 2312-0967. Pharmaceutical review. 2017. № 2 
Фітохімічні дослідження

\section{Phytochemical researches}

7. State Pharmacopoeia of Ukraine. [Державна фрармакопея України: в 3 т.] Kharkov: Ukrainian Scientific Pharmacopoeial Center of Quality of medicines 2 ed. X; 2008. Ukrainian.

8. Ad'hiah Ali H, Orooba NH Al-Bederi, Khulood W Al-Sammarrae. Cytotoxic effects of Agrimonia eupatoria L. against cancer cell lines in vitro. J. Ass Arab Universities Basic and Applied Sci. 2013;14: 87-92.

9. Ki Yong Lee, Lim Hwang, Eun Ju Jeong, Seung Hyun Kim, Young Choong Kim, Sang Hyun Sung. Effect of neuroprotective flavonoids of Agrimonia eupatoria on glutamateinduced oxidative injury to HT22 hippocampal cells. Biosc Biotech and Biochem. 2010;74(8): 1704-6. Available from: https://www.jstage.jst.go.jp/browse/bbb/74/8/_contents 10. AGRIMONIA - AGRIMONY (AGRIMONIAE HERBA) Available from: https://herbalref.com/agrimonia-agrimonyagrimoniae-herba/

11. Chubka MB, Vrons'ka LV, Sur SV, Smalyuh OG, Kernychna IZ. [Spectrophotometric determination of flavonoids in the garden carrot (Daucus carota L.) seeds]. Med Chem. 2011;1: 88-94. Ukrainian. Available from: http://ojs. tdmu.edu.ua/index.php/med-chem/article/view/231

12. Evdokimova OV. [Validation for a procedure for assay of the amount of flavonoids in Stuli cum stigmatis Zea Maydis]. Farmatsiia. 2008;7: 14-7. Russian.

13. Shumova AS, Evtifeeva OA, Georgiyants VA. [Development the method of quantitative determination flavonoids different types of medicinal plants by spectrophotometric method and determination of its validation performance]. Phytotherapy.2013;2: 48-52. Ukrainian.

14. Granica S, Krupa K, Klębowska A, Kiss AK. Development and validation of HPLC-DAD-CAD-MS3 method for qualitative and quantitative standardization of polyphenols in Agrimoniae eupatoriae herba (Ph. Eur). J Pharm Biomed Anal. 2013;86(12): 112-122. Available from: https://doi. org/10.1016/j.jpba.2013.08.006

15. Kurkina AV. [Actual aspects of standardization of medicinal vegetative raw materials containing flavonoids]. Pharm Chem J. 2011;45(1): 31-4. Russian.

16. Correia HS, Batista MT, Dinis TCP. The activity of an extract and fraction of Agrimonia eupatoria L. against reactive species. BioFactors. 2007;29(2): 91-104. Available from: http://onlinelibrary.wiley.com/doi/10.1002/biof.552029209/ full

17. Santos TN, Costa G, Ferreira JP, Liberal J, Francisco V, Paranhos A, et al. Antioxidant, Anti-Inflammatory and Analgesic Activities of Agrimonia eupatoria L. Infusion. Pub Evidence-Based Complementary and Alternative Med Volume. 2017 Apr 12. Available from: https://doi. org/10.1155/2017/8309894.

18. Yoon SJ, Koh EJ, Kim CS, Zee OP, Kwak JH, Jeong WJ, et al. Agrimonia eupatoria protects against chronic ethanolinduced liver injury in rats. Food Chem Toxicol. 2012;50(7): 2335-41. Available from: doi: 10.1016/j.fct.2012.04.005. Epub 2012 Apr 16.

19. Kwon DH1, Kwon HY, Kim HJ, Chang EJ, Kim MB, Yoon SK, et al. Inhibition of hepatitis B virus by an aqueous extract of Agrimonia eupatoria L. Phytotherapy Res. 2005;19(4): 355-8. Available from: https://www.ncbi.nlm. nih.gov/pubmed/16041735

20. Zhang J, Chen Y. Studies on the lowering blood sugar substances from agrimony. J Chinese Med Mat. 2009;32: 1537-9. Available from: https://www.ncbi.nlm.nih.gov/ pubmed/20112714 